\title{
Monitoring and Assessment of Ocean Acidification in the Arctic Ocean: A Scoping Paper
}

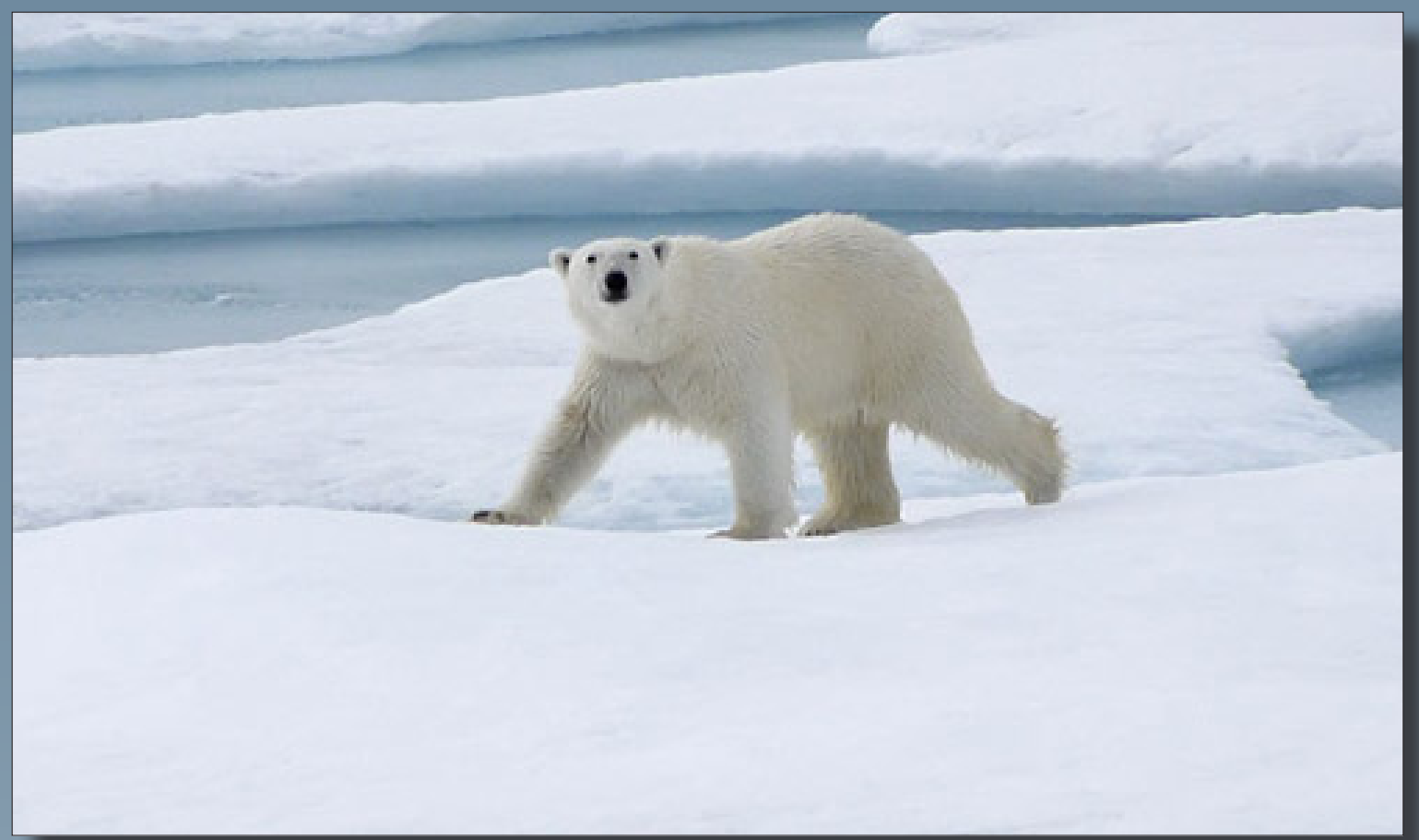

Open-File Report 2010-1227

U.S. Department of the Interior U.S. Geological Survey 
Cover. Polar bear in the Beaufort Sea, August 9, 2010. (Photograph taken by Bill Schmoker. Used with permission.) 


\section{Monitoring and Assessment of Ocean Acidification in the Arctic Ocean: A Scoping Paper}

By Lisa L. Robbins, Kimberly K. Yates, Richard Feely, and Victoria J. Fabry

Open-File Report 2010-1227 


\title{
U.S. Department of the Interior \\ KEN SALAZAR, Secretary \\ U.S. Geological Survey \\ Marcia K. McNutt, Director
}

\section{U.S. Geological Survey, Reston, Virginia: 2010}

\author{
For more information on the USGS — the Federal source for science about the Earth, its natural and living resources, \\ natural hazards, and the environment, visit http://www.usgs.gov or call 1-888-ASK-USGS \\ For an overview of USGS information products, including maps, imagery, and publications, \\ visit http://www.usgs.gov/pubprod \\ To order this and other USGS information products, visit http://store.usgs.gov
}

\begin{abstract}
Any use of trade, product, or firm names is for descriptive purposes only and does not imply endorsement by the U.S. Government.

Although this report is in the public domain, permission must be secured from the individual copyright owners to reproduce any copyrighted materials contained within this report.
\end{abstract}

Suggested citation:

Robbins, L.L., Yates, K.K., Feely, Richard, and Fabry, V.J., 2010, Monitoring and assessment of ocean acidification in the Arctic Ocean-A scoping paper: U.S. Geological Survey Open-File Report 2010-1227, 4 p. 


\section{Contents}

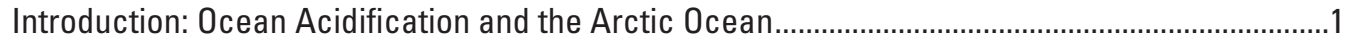

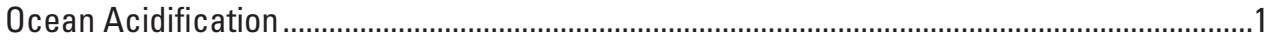

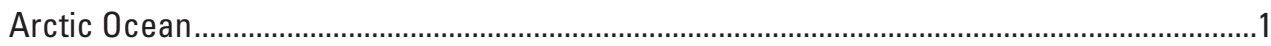

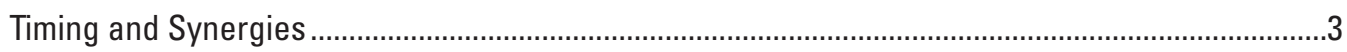

What Important Information Needs Have Been Identified? .............................................................

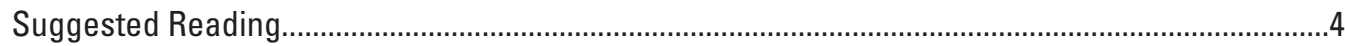

\section{Figures}

1. International Bathymetric Chart of the Arctic Ocean..........................................................

2. International programs involved in Arctic research.............................................................. 



\title{
Monitoring and Assessment of Ocean Acidification in the Arctic Ocean: A Scoping Paper
}

\author{
By Lisa L. Robbins, ${ }^{1}$ Kim K. Yates, ${ }^{1}$ Richard Feely, ${ }^{2}$ and Victoria J. Fabry ${ }^{3}$
}

\section{Introduction: Ocean Acidification and the Arctic Ocean}

\section{Ocean Acidification}

Carbon dioxide $\left(\mathrm{CO}_{2}\right)$ in the atmosphere is absorbed at the ocean surface by reacting with seawater to form a weak, naturally occurring acid called carbonic acid. As atmospheric carbon dioxide increases, the concentration of carbonic acid in seawater also increases, causing a decrease in ocean $\mathrm{pH}$ and carbonate mineral saturation states, a process known as ocean acidification. The oceans have absorbed approximately 525 billion tons of carbon dioxide from the atmosphere, or about one-quarter to one-third of the anthropogenic carbon emissions released since the beginning of the Industrial Revolution. Global surveys of ocean chemistry have revealed that seawater $\mathrm{pH}$ has decreased by about 0.1 units (from a $\mathrm{pH}$ of 8.2 to 8.1) since the 1700s due to absorption of carbon dioxide (Raven and others, 2005). Modeling studies, based on Intergovernmental Panel on Climate Change (IPCC) $\mathrm{CO}_{2}$ emission scenarios, predict that atmospheric carbon dioxide levels could reach more than 500 parts per million (ppm) by the middle of this century and 800 ppm by the year 2100 , causing an additional decrease in surface water $\mathrm{pH}$ of $0.3 \mathrm{pH}$ units. Ocean acidification is a global threat and is already having profound and deleterious effects on the geology, biology, chemistry, and socioeconomic resources of coastal and marine habitats. The polar and sub-polar seas have been identified as the bellwethers for global ocean acidification.

\section{Arctic Ocean}

The Arctic Ocean covers an area of 14,056,000 square kilometers $\left(\mathrm{km}^{2}\right)$ (fig. 1), has a fairly constant temperature of 32 degrees Fahrenheit $\left({ }^{\circ} \mathrm{F}\right)$, and supports some of the

\footnotetext{
${ }^{1}$ U.S. Geological Survey, St. Petersburg, FL 33705.

${ }^{2}$ National Oceanic and Atmospheric Administration, Seattle, WA 98115.

${ }^{3}$ California State University San Marcos, San Marcos, CA 92096.
}

most productive marine areas in the world. Its cold waters absorb carbon dioxide more rapidly than it is absorbed by warmer seawater. Increasing temperature $\left(1.8^{\circ} \mathrm{F}\right.$, over the past 150 years) has increased melting of Arctic ice. Up until recently, the perennial ice cover has prohibited significant equilibration with the atmosphere, creating a polar mixed layer that has lower partial pressure of $\mathrm{CO}_{2}$ levels than those found in the atmosphere. Over the last three decades, retreat of summertime sea ice cover has exposed shelf waters to the atmosphere and has allowed additional absorption of atmospheric $\mathrm{CO}_{2}$. The combination of these processes accelerates the rate at which $\mathrm{pH}$ and carbonate mineral saturation state decrease. Models have projected that the entire Arctic Ocean will become undersaturated with respect to carbonate minerals in the next decade. However, some recent field results indicate that parts of the Arctic Ocean may already be undersaturated in the late summer months, when ice melt is at its largest extent. The uncertainty of the models is based on lack of data. A systematic approach to measuring the chemistry of the Arctic Ocean has not been attempted, and baselines to gage future change have not been established.

Decreased $\mathrm{pH}$ and mineral saturation state impair the ability of many fish and shellfish to grow and will affect many parts of the food chain, from primary producers to higher trophic organisms. High-latitude marine organisms often exhibit low metabolic rates and very slow development and growth rates when compared with similar taxa at mid- or low latitudes. Because of their prolonged life histories, fewer generations will have opportunities for successful acclimation or adaptation to seawater that will become progressively elevated in dissolved $\mathrm{CO}_{2}$. Although many physiological processes in diverse organisms may be affected by rising ocean acidity, the declining carbonate mineral saturation states of aragonite and calcite in surface waters, and establishment of corrosive conditions in some regions may particularly impact high-latitude planktonic and benthic calcifiers. Because of these factors, marine food supplies could be reduced with significant implications for food production and security for indigenous populations that are dependent on fish protein. Due to the immediacy of the ocean acidification threat in the Arctic and limited observations to support model results that demonstrate significant change in the polar oceans, ocean 


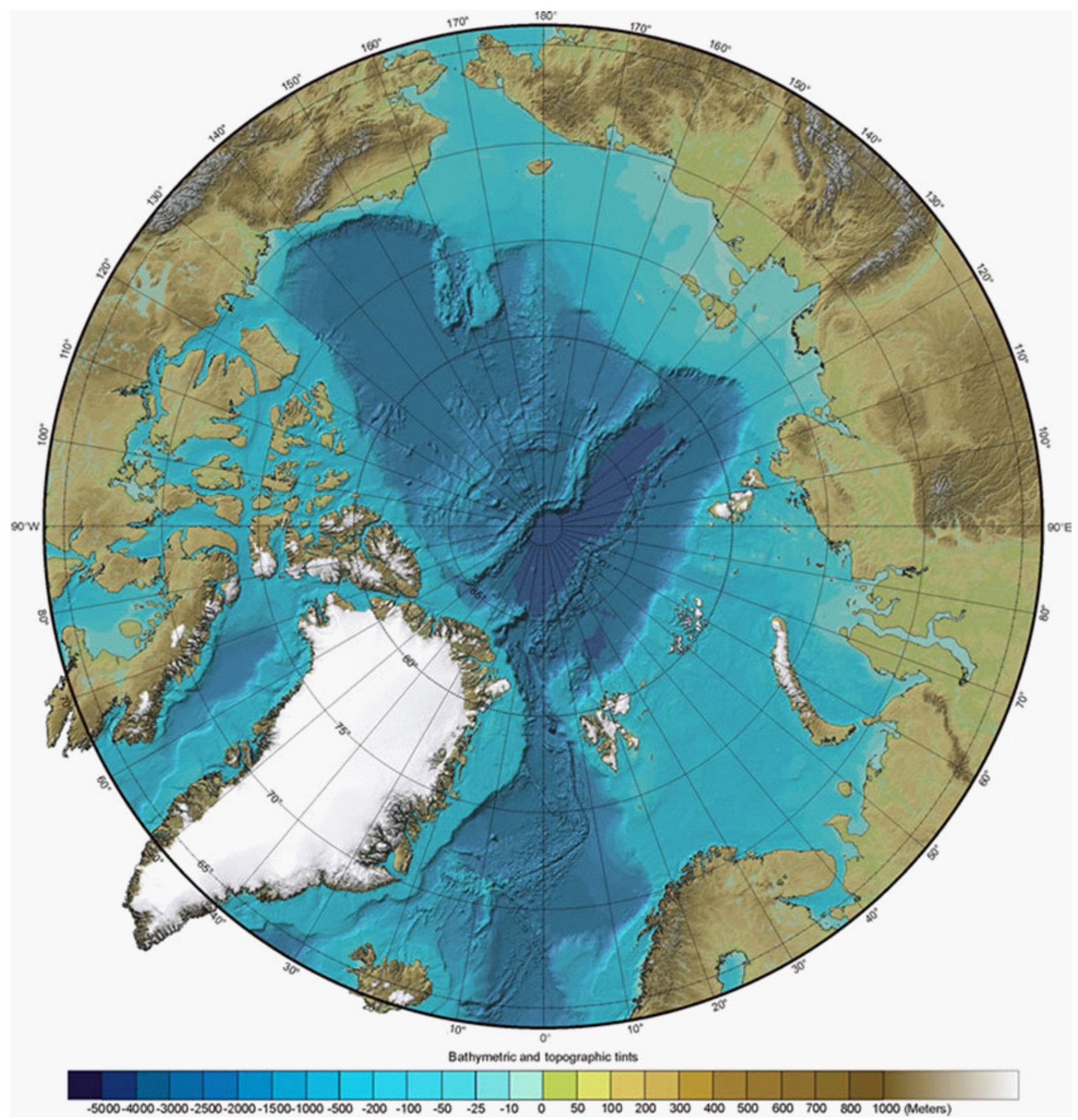

Figure 1. International Bathymetric Chart of the Arctic Ocean (Jakobsson and others, 2008).

acidification has emerged as a top priority within the United States and international organizations, including:

- Ocean Carbon and Biogeochemistry Program (OCB)

- Integrated Marine Biogeochemistry and Ecosystem Research Project (IMBER)

- Scientific Committee on Oceanic Research (SCOR)

- UNESCO’s Intergovernmental Oceanographic Commission (IOC)
- International Atomic Energy Agency (IAEA) Marine Environment Laboratories

- Surface Ocean Lower Atmosphere Study (SOLAS)

- International Geosphere-Biosphere Program [IGBP; for example, the Past Global Changes (PAGES) Project]

- Consortium for Ocean Leadership (COL) 


\section{Timing and Synergies}

Evidence for accelerated ocean acidification in the Arctic Ocean and its potentially profound consequences place urgency on the development of a circumpolar monitoring and assessment effort. This can be achieved through a concerted international effort with synergies of the many international organizations and programs already working in the Arctic (fig. 2).

Major ocean acidification studies are underway or are in advanced stages of planning world wide with a focus on highlatitude environments. The European Commission has funded the European Project on OCean Acidification (EPOCA), an initiative to investigate "ocean acidification and its consequences" as a multinational effort that includes 29 laboratories located in nine European countries. One of EPOCA's priorities is to establish a strong E.U.-U.S. collaboration on ocean acidification research in high-latitude regions. In addition, two anticipated national programs within E.U. home countries will augment EPOCA research: in the U.K., a 5-year program to investigate changes in ocean ecosystems in response to ocean acidification (funded by the Natural Environment Research Council) and, in Germany, a program entitled Biological Impacts of Ocean Acidification (BIOACID) (funded by Bundesministerium fur Bildung und Forschung, the Federal Ministry of Education and Research). Further, Federal organizations within the United States (National Oceanic and Atmospheric Administration, U.S. Geological Survey, National Science Foundation, National Aeronautics and Space Administration, Bureau of Ocean Energy Management, U.S. State Department, Environmental Protection Agency) are developing research plans under the authority of the Federal Ocean Acidification Research and Monitoring Act of 2009.

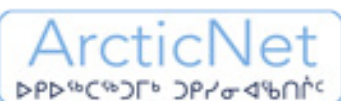

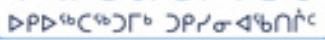
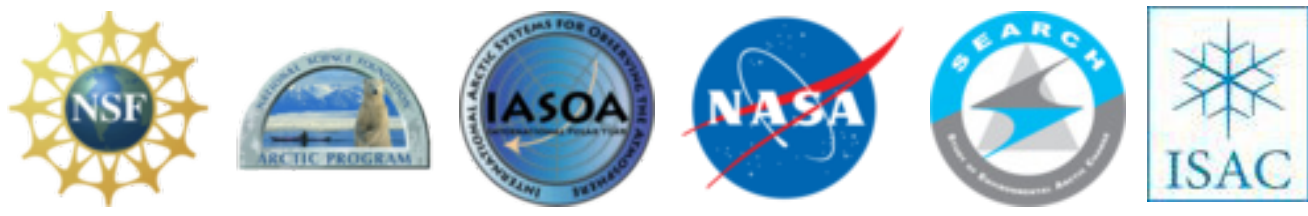
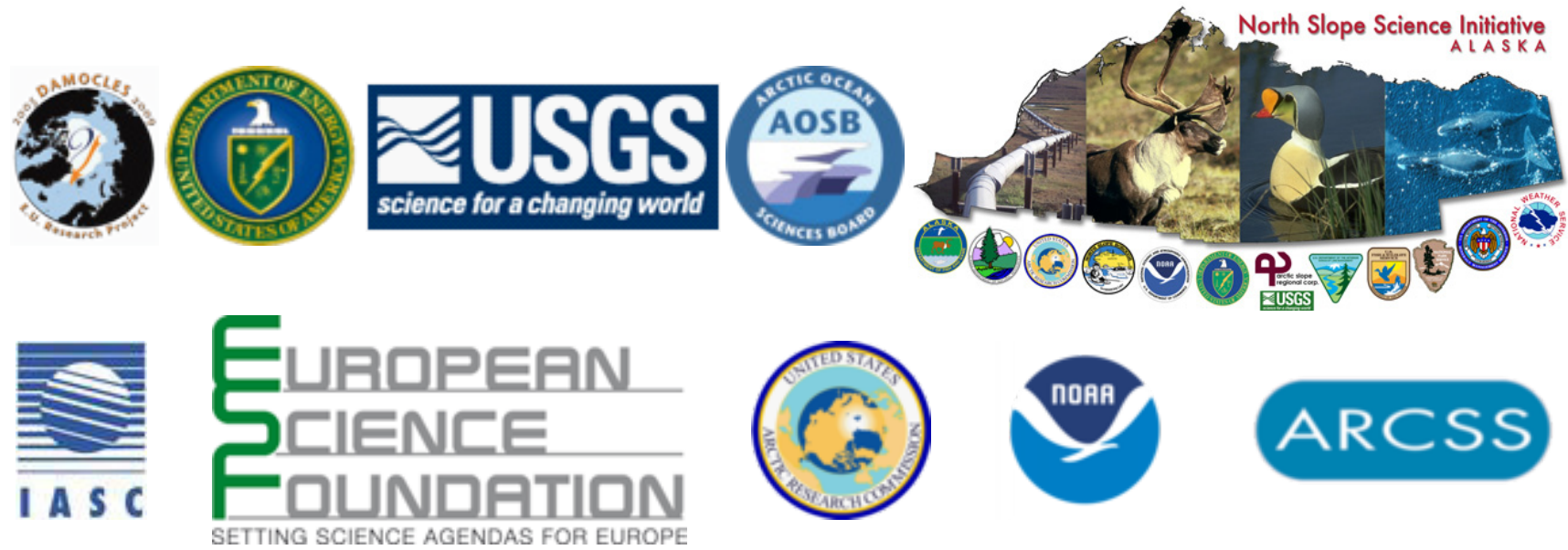

Figure 2. International programs involved in Arctic research.

Top row from left to right: Arctic Net, National Science Foundation (NSF) and NSF Arctic Program, International Arctic Systems for Observing the Atmosphere (IASOA), National Aeronautics and Space Administration (NASA), Study of Environmental Arctic Change (SEARCH), International Study of Arctic Change (ISAC)

Middle row from left to right: European Union Damocles Project, U. S. Department of Energy (DOE), U.S. Geological Survey (USGS), Arctic Ocean Science Board (AOSB), North Slope Science Initiative, Alaska

Bottom row from left to right: International Arctic Science Committee (IASC), European Science Foundation (ESF), U.S. Arctic Research Commission, National Oceanic and Atmospheric Administration (NOAA), NSF Arctic System Science Program (ARCSS) 


\section{What Important Information Needs Have Been Identified?}

There are few data to confirm how the Arctic Ocean and its marine ecosystems respond to ocean acidification. A report by the OCB subcommittee on Ocean Acidification (http://www.us-ocb.org/publications/OCB_OA_Whitepaper. $p d f$ ), citing a number of reports from workshops, has outlined research gaps and U.S. agencies that are well positioned to undertake these studies, including

- seasonal monitoring of open ocean, coastal, and "under ice" seawater chemistry, including inorganic and organic carbon measurements, other carbonate system parameters, and related isotopes, with a high degree of spatial and temporal resolution;

- high-quality surveys, mapping, and measurements to assess the abundances and depth distributions of planktonic and benthic organisms, seafloor habitat and bathymetry, and carbonate sediment distribution;

- laboratory and field experiments to examine geological and biological response; and

- ecosystem-scale studies.

Among priority locations and key habitats, the OCB report considers the high-latitude region of the Arctic as critical due to a severe lack of basic data that characterize the region, establish baselines for monitoring climate change impacts, and validate model results that indicate the extent of Arctic Ocean vulnerability. The OCB report suggests that monitoring and network observations within this key habitat be established within the next 5 years. Expanded time series studies of coastal and open ocean seawater chemistry will allow scientists to monitor the progress of ocean acidification and to place it in the context of other global climate change studies.

\section{Suggested Reading}

Andersson, A.J., Mackenzie, F.T., and Bates, N.R., 2008, Life on the margin - Implications of ocean acidification on Mg-calcite, high latitude, and cold-water marine calcifiers: Marine Ecology Progress Series, v. 373, p. 265-273.

Bates, N.R., and Mathis, J.T., 2009, The Arctic Ocean marine carbon cycle - Evaluation of air-sea $\mathrm{CO}_{2}$ exchanges, ocean acidification impacts and potential feedbacks: Biogeosciences Discussions, v. 6, p. 6695-6747.

Bates, N.R., Moran, S.B., Hansell, D.A., and Mathis, J.T., 2006, An increasing $\mathrm{CO}_{2}$ sink in the Arctic Ocean due to sea-ice loss: Geophysical Research Letters, v. 33, L23609, 7 p., doi:10.1029/2006GL027028.
Comeau, S., Gorsky, G., Jeffree, R., Teyssie, J.-L., and Gattuso, J.-P., 2009, Impact of ocean acidification on a key Arctic pelagic mollusc (Limacina helicina): Biogeosciences, v. 6, no. 9, p. 1877-1882.

Fabry, V.J., McClintock, J.B., Mathis, J.T., and Grebmeier, J.M., 2009, Ocean acidification at high latitudes - The bellwether: Oceanography, v. 22, no. 4, p. 160-171.

Jakobsson, M., Macnab, R., Mayer, L., Anderson, R., Edwards, M., Hatzky, J., Schenke, H.-W., and Johnson, P., 2008, An improved bathymetric portrayal of the Arctic Ocean-Implications for ocean modeling and geological, geophysical and oceanographic analyses: Geophysical Research Letters, v. 35, L07602, 5 p., doi:10.1029/2008GL033520.

Mathis, J.T., Bates, N.R., Hansell, D.A., and Babila, Tali, 2009, Net community production in the northeastern Chukchi Sea: Deep Sea Research II, v. 56, p. 1213-1222.

Olafsson, J., Olafsdottir, S.R., Benoit-Cattin, A., Danielsen, M., Arnarson, T.S., and Takahashi, T., 2009, Rate of Iceland Sea acidification from time series measurements: Biogeosciences, v. 6, no. 11, p. 2661-2668.

Raven, J., Caldeira, K., Elderfield, H., Hoegh-Guldberg, O., Liss, P.S., Reisbell, U., Shepard, J., Turley, C., and Watson, A.J., 2005, Ocean acidification due to increasing atmospheric carbon dioxide: London, The Royal Society, Policy Document, $60 \mathrm{p}$.

Schuster, U., Watson, A.J., Bates, N.R., Corbière, A., González-Dávila, M., Metzl, N., Pierrot, D., and SantanaCasiano, M., 2009, Trends in North Atlantic sea-surface $\mathrm{fCO}_{2}$ from 1990 to 2006: Deep-Sea Research, Part II, v. 56, p. $620-629$.

Steinacher, M., Joos, F., Frölicher, T.L., Plattner, G.-K., and Doney, S.C., 2009, Imminent ocean acidification in the Arctic projected with the NCAR global coupled carbon cycleclimate model: Biogeosciences, v. 6, no. 4, p. 515-533.

Steinacher, Marco, Joos, Fortunat, and Frölicher, T.L., 2009, Box 5. Modeling ocean acidification in the Arctic Ocean, in Gattuso, J.-P., Hansson, Lina, and the EPOCA Consortium, European Project on Ocean Acidification (EPOCA) Objectives, products, and scientific highlights: Oceanography, v. 22, no. 4, p. 198-199.

Takahashi, Taro, Sutherland, S.C., Wanninkhof, Rik, and others, 2009, Climatological mean and decadal change in surface ocean $\mathrm{pCO}_{2}$, and net sea-air $\mathrm{CO}_{2}$ flux over the global oceans: Deep-Sea Research, Part II, v. 56, p. 554-577.

Watson, A.J., Schuster, Ute, Bakker, D.C.E., and others, 2009, Tracking the variable North Atlantic sink for atmospheric $\mathrm{CO}_{2}$ : Science, v. 326, p. 1391-1393.

Yamamoto-Kawai, Michiyo., McLaughlin, F.A., Carmack, E.C., Nishino, Shigeto, and Shimada, Koji, 2009, Aragonite undersaturation in the Arctic Ocean-Effects of ocean acidification and sea ice melt: Science, v. 326, no. 1098, p. 1098-1100. 


\section{营}

끔

言

옿

$\frac{0}{5}$

흘.

言

要

眾

产

음

윰

홈.

胥

홍

용

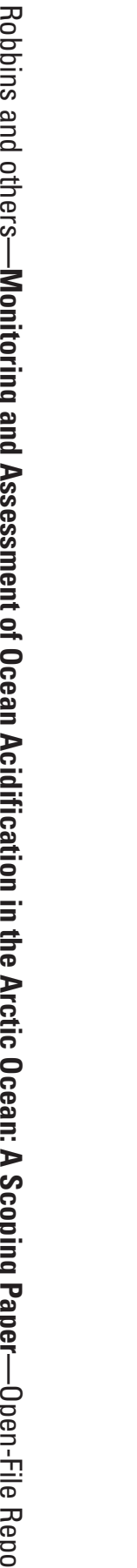

